\title{
Rancang Bangun Sistem Hidung Elektronik Berbasis Sensor Gas MQ untuk Mengevaluasi Kualitas Madu
}

\author{
Minarni Shiddiq ${ }^{(\mathrm{a}) *}$, Annisa Fadlilah $^{(\mathrm{b})}$, Sinta Afria Ningsih ${ }^{(\mathrm{c})}$, dan \\ Ikhsan Rahman Husein ${ }^{(\mathrm{d})}$ \\ Jurusan Fisika Universitas Riau, Pekanbaru, Indonesia, 28293 \\ Email: $:^{\left(a^{*}\right)}$ minarni.shiddiq@lecturer.unri.ac.id, ${ }^{(b)}$ annisafadlillah92@gmail.com, ${ }^{(c)}$ sintaafria16@gmail.com, \\ (d)ikhsanrahman.a@gmail.com
}

Diterima (01 Januari 2021), Direvisi (27 Juli 2021)

\begin{abstract}
Honeys come in many varieties based on quality attributes and region origins. Electronic nose systems have been adopted and used to classify honey types based on physicochemical parameters. This study was aimed to build a low cost electronic nose (e-nose) based on metal oxide semiconductor (MOS) gas sensors, and then used to evaluate the qualities of two types of honeys and one non honey based on sugar contents and $p H$ values. Six gas sensors of $M Q$ modules namely $M Q$ 2, $M Q$ 3, $M Q$ 4, $M Q 5, M Q 6, M Q 9$, and an Arduino microcontroller were used in this system. Software of Arduino IDE, PLX-DAQ, and Python were applied to record output voltages of each sensor, saved in Excel format, and to calculate trapezoid areas respectively. The honey types were a branded honey, a local forest honey, and date syrup, respectively. The results show higher output voltages for three sensors which are $M Q 3, M Q 4$, and $M Q 6$. The six sensors are able to differentiate between the two honey types and non honey. Non honey, date syrup has the lowest trapezoid area. This could be caused by its higher $p H$ value. The results also show that higher sugar contents give higher trapezoid area which is shown by the branded honey. However, response of each sensor for honey is different than both local type and date syrup. This shows that volatile compounds can cause higher trpeazoid area for the branded honey.
\end{abstract}

Keywords: Electronic nose, honey, $M Q$ gas sensor, $p H$ values, sugar content

\begin{abstract}
Abstrak. Madu tersedia di pasaran bervariasi dalam hal kualitas dan asal daerah. Sistem hidung elektronik telah diadopsi dan dikembangkan untuk mengklasifikasi kualitas madu berdasarkan sifat fisika dan kimia madu. Penelitian ini bertujuan membangun sistem hidung elektronik mengunakan sensor gas seri MQ dalam bentuk modul, selanjutnya digunakan untuk mengevaluasi dua jenis madu dan satu jenis bukan madu berdasarkan kadar gula dan nilai pH. Enam sensor yaitu MQ2, MQ3, MQ4, MQ5, MQ6, MQ9, dan sebuah mikrokontroler Arduino digunakan pada sistem ini. Software arduino IDE, PLX-DAQ, dan Python masingmasing dirancang untuk proses akuisisi, konversi tegangan keluaran dalam format excel, dan.perhitungan luas area trapezoid. Jenis-jenis madu tersebut meliputi madu bermerk Nasional yang memenuhi SNI 013545-2013, madu hutan lokal, dan sari kurma. Hasil penelitian menunjukkan bahwa tiga dari enam sensor gas yang digunakan yaitu MQ 3, MQ 4, dan MQ 6 menghasilkan respon tegangan yang lebih tinggi. Keenam sensor dapat membedakan larutan dari dua jenis madu yaitu madu SNI, madu hutan, dan sari kurma. Non madu sari kurma menghasilkan luas area trapezoid yang lebih rendah dibanding kedua jenis madu. Ini dapat disebabkan karena nilai $\mathrm{pH}$ non madu sari kurma yang lebih tinggi. Hasil juga menunjukkan bahwa kadar gula yang tinggi yaitu Madu SNI menghasilkan luasan trapezoid yang lebih tinggi. Namun respon setiap sensor untuk madu SNI berbeda dengan respon sensor untuk jenis madu hutan dan sari kurma, yang menunjukkan kandungan volatil berbeda juga menyebabkan tingginya luas trapezoid madu SNI.
\end{abstract}

Kata kunci: Hidung elektronik, kadar gula, madu, nilai pH, sensor gas MQ 


\section{PENDAHULUAN}

Metode penentuan mutu dan keaslian berbagai produk makanan secara elektronik lebih disukai dibanding metode manual dan tradisional karena bersifat objektif, otomatis, cepat, data dapat disimpan untuk evaluasi lebih lanjut. Saat ini metode nondestruktif yang menirukan cara kerja panca indera manusia yang disebut indera buatan (artificial senses) telah dikembangkan untuk tujuan tersebut. Indera buatan tersebut antara lain computer vision dengan kamera, hidung elektronik (e-nose) dengansensor gas, dan lidah electronik (etongue) dengan voltametri [1]. Beberapa tahun terakhir, gabungan dari indera buatan digunakan untuk mengevaluasi kualitas produk makanan yang lebih akurat $[2,3]$

Pengembangan hidung elektronik telah banyak dilakukan untuk kualitas bahan makanan dan produk pertanian, terutama untuk membangun sistem hidung elektronik yang ekonomis, kompak, dan portabel. Hidung elektronik adalah sebuah sistem elektronik yang terdiri dari larik sensorsensor gas atau aroma yang diintegrasikan dengan rangkaian sistem kendali dan program komputer sehingga dapat menirukan fungsi indera penciuman manusia. Hidung elektronik mempunyai aplikasi yang luas pada bidang medis, lingkungan, pertanian, dan farmasi [4].

Kualitas madu merupakan faktor utama yang digunakan konsumen dalam memilih suatu produk madu. Madu adalah pemanis alami yang dihasilkan oleh lebah madu dari berbagai nektar tanaman. Nilai gizi yang terkandung dalam madu berbeda dengan jenis pemanis lainnya sehingga madu banyak digunakan pada bidang kesehatan dan industri makanan [5]. Kualitas madu dapat ditentukan secara tradisional dengan uji organoleptik berdasarkan warna, rasa, dan aroma dengan mengunakan panca indera konsumen. Cara lainnya adalah pengujian secara sederhana seperti madu asli yang tidak terbakar jika diletakkan pada kapas, tidak mudah diserap oleh kertas, atau tidak mudah larut dalam air hangat. Uji mengunakan alat sederhana seperti refraktometer Brix juga banyak dilakukan khususnya bagi peternak madu untuk menentukan kadar gula atau kadar air madu. Uji laboratorium berdasarkan sifat fisika dan kimia madu seperti kadar keasaman (nilai $\mathrm{pH}$ ), kadar air atau kadar gula, dan kandungan kimia lainnya juga sering dilakukan $[6,7]$. Metode yang lebih akurat adalah metode spektroskopi seperti spektroskopi FTIR dan UV-VIS [8]. Metode organoleptik bersifat subyektif dan bergantung pada personil yang berpengalaman, sedangkan metode dengan brixmeter bersifat destruktif dan manual. Metode spektroskopi memerlukan personil yang terlatih dan waktu yang lama, serta cenderung destruktif.

Aroma madu seperti halnya makanan lainnya adalah salah satu sifat khas yang sering digunakan konsumen untuk memilih suatu produk. Aroma ini disebabkan oleh senyawa volatil yang terdapat pada madu diantaranya yaitu aldehida, keton, asam karbksilat, alkohol, hidrokarbon, ester, senyawa norisoprenoid, senyawa terpena dan benzena $[9,10]$.

Aroma yang dihasilkan madu juga dapat digunakan untuk menentukan asal dari sumber nektarnya. Nektar dan sumber sari tanaman mempengaruhi sifat fisika dan kimia madu yang menjadi parameter untuk menentukan kualitas madu [10]. Oleh sebab itu, hidung elektronik dapat digunakan untuk menentukan kualitas madu berdasarkan aroma yang dikeluarkan oleh senyawa volatil setiap jenis madu.

Sistem hidung elektronik secara umum terdiri dari 6 bagian utama. Bagian-bagian tersebut yaitu bagian sampel, larik sensor gas, pengkondisi sinyal, sistem kendali, program akuisisi data, pengenalan pola dan metode klasifikasi [11]. Bagian sampel berupa ruang sampel dan sistem aliran 
fluida gas dari sampel menuju ruang sensor. Larik sensor berupa kumpulan sensor gas yang mengubah gas menjadi arus listrik dan tegangan listrik. Tegangan listrik diperkuat disaring oleh rangkaian penguat, kemudian menjadi input mikrokontroler seperti Arduino. Program IDE arduino atau program akuisisi data lainnya dibuat untuk kemudahan perekaman dan penyimpangan data tegangan. Selanjutnya pengenalan pola (pattern recognition) dan data analysis untuk klasifikasi dilakukan [12].

Pada penelitian ini, sistem hidung elektronik didesain dan dibuat untuk mengevaluasi kualitas madu berdasarkan kadar gula dan nilai $\mathrm{pH}$. Sistem ini mengunakan 6 sensor gas seri MQ dengan sensitivitas gas yang berbeda. Jenis sensor ini tersedia dalam bentuk modul sehingga memungkinkan untuk membangun sistem hidung elektronik yang ekonomis dan sederhana. Program Python digunakan karena bersifat open source dan memberi kemudahan dalam pembuatan program pengolahan data tegangan dan pengambilan keputusan mengunakan artificial inteligence (AI) dibanding platform perangkat lunak lainnya [13].

\section{METODE PENELITIAN}

Metode yang digunakan pada penelitian ini adalah metode eksperimen yaitu mengembangkan sistem hidung elektronik mengunakan sensor MOS (metal oxide semiconductor) seri MQ untuk mengevaluasi kualitas madu. Sistem ini terdiri dari beberapa bagian utama yang unjuk kerja sensor gas MOS pada sistem hidung elektronik digunakan untuk menentukan kualitas madu. Sistem hidung elektronik yang dibangun terdiri dari ruang sampel, ruang sensor, dan ruang arduino, kemudian mikrokontroler Arduino. Selanjutnya program akuisisi data dan analisa data dibuat untuk automatisasi [11, 12].
Tabel 1.Sensor gas MQ yang digunakan*

\begin{tabular}{cl} 
Jenis & Sensitivitas utama terhadap gas \\
\hline MQ 2 & Methane, Butane, LPG, Smoke \\
MQ 3 & Alkohol, Ethanol, Smoke \\
MQ 4 & Methane, Propane, Butane \\
MQ 5 & Natural Gas, LPG \\
MQ 6 & LPG, butane \\
MQ 9 & CO, flammable gas \\
\hline
\end{tabular}

- Sumber:hwsensor.com, [14]

Bahan dan alat yang digunakan adalah dua jenis madu dan satu non madu, enam sensor gas seri MQ dalam bentuk modul, mikrokontroler Arduino Atmega 2560, sensor DHT 11, LM 317, kabel jumper, power supply, perangkat lunak akuisisi data, dan laptop.

Tabel 1 memperlihatkan 6 sensor gas logam oksida yang digunakan yaitu seri MQ2, MQ3, MQ4, MQ 5, MQ6, dan MQ9. Sensor-sensor ini dipilih karena tersedia dalam bentuk modul, mudah diintegrasikan ke mikrokontroler Arduino, berhubungan dengan senyawa volatil yang dikeluarkan madu pada umumnya $[9,10]$.

Penelitian ini dilakukan dalam beberapa tahapan. Tahapan-tahapan tersebut adalah persiapan alat dan sampel, perakitan perangkat keras sistem hidung, pembuatan perangkat lunak akuisisi dan analisa data. Tahapan selanjutnya adalah persiapan sampel dan pengukuran kadar gula dan nilai $\mathrm{pH}$, kalibrasi sistem, dan pengukuran tegangan keluaran setiap sensor untuk ketiga jenis sampel. Tahapan berikutnya adalah menghitung luas trapezoid dari fungsi tegangan keluaran terhadap waktu untuk setiap jenis sensor pada ketiga jenis sampel. Tahapan terakhir adalah menganalisa hubungan antara luas trapezoid dan kadar gula dan nilai $\mathrm{pH}$. 


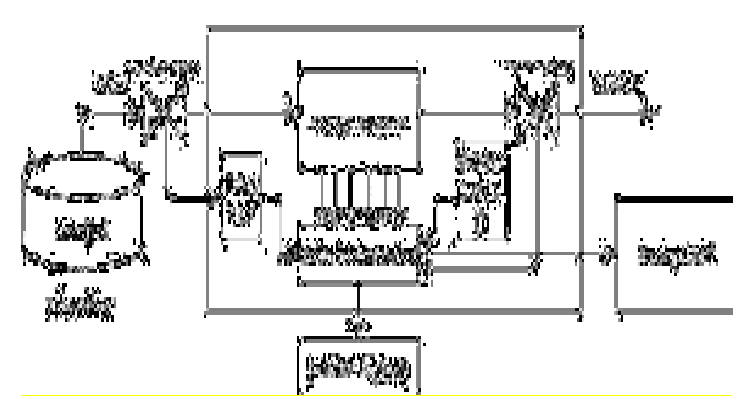

Gambar 1. Diagram blok sistem

\section{Pembuatan Sistem Hidung Elektronik}

Sistem ini terdiri dari dua bagian ruang (chamber) yaitu ruang sampel dan ruang sensor. Gambar 1 memperlihatkan skema dari sistem hidung elektronik yang dibangun. Ruang sensor dibuat dari kotak akrilik yang berukuran $13 \times 10 \times 18 \mathrm{~cm}$ yang terbagi menjadi dua bagian. Bagian atas yaitu ruang larik sensor berukuran 13x10x8 $\mathrm{cm}$ yang terdiri dari 6 modul sensor gas dan sensor DHT 11, serta pompa vakum. Bagian bawah berukuran 13x10x10 cm terdiri dari arduino dan perkabelan (kabel jumper). Kotak akrilik ini dibagi dua bertujuan agar ruangan sensor tidak terkontaminasi oleh bau kabel. Saat sensor gas dioperasikan, ruang larik sensor akan panas. Jika pengkabelan berada dalam ruang sensor, kabel akan panas dan cepat rusak, sehingga bau kabel dapat memasuki ruang di ruang larik sensor.

Komponen penunjang pada sistem ini antara lain adalah pompa vakum, power supply, pompa vakum digunakan pada sistem ini untuk membersihkan ruang larik sensor dari gas yang tersisa (purging). Sistem ini membutuhkan power supply eksternal untuk mencatu enam sensor gas seri MQ dan komponen lainnya.

Aliran aroma atau gas dari senyawa volatil dari madu menuju larik sensor dihubungkan oleh sistem aliran fluida (headspace) yang terdiri dari ruang sampel, pompa vakum terintegrasi dengan Arduino

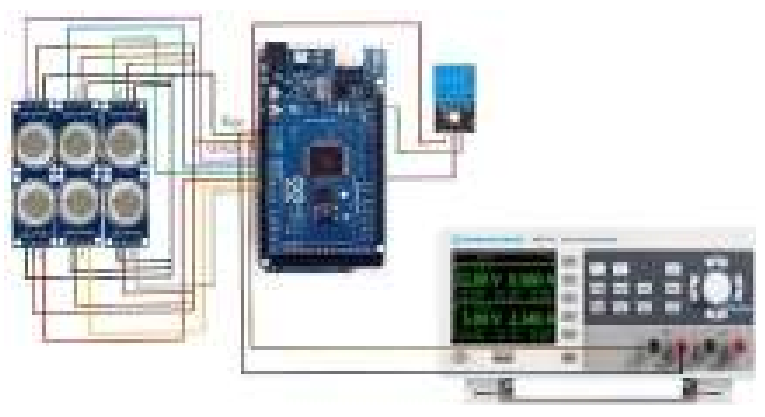

Gambar 2. Koneksi larik sensor gas MQ ke Arduino

dan selang oksigen. Ruang sampel berupa toples silinder yang bagian atas penutupnya dilubangi untuk tempat selang dan pompa vakum. Toples dipilih yang mempunyai penutup dengan ulir yang banyak sehingga ketika ditutup akan kedap udara. Penutup juga digunakan agar sampel madu dalam cawan petri dapat dimasukkan. Pompa vakum bekerja secara otomatis berdasarkan waktu yang sudah diatur pada program arduino dengan bantuan LM 317 sebagai gerbang logikanya. Selang berfungsi sebagai transfusi gas dari ruang sampel ke ruang larik sensor gas.

Gambar 2 memperlihatkan koneksi pin dari setiap sensor gas ke papan mikrokontroler Arduino. Sistem hidung elektronik mengunakan mikrokontroler Arduino Atmega 2560 untuk pengendali ke enam sensor. Sensor gas seri MQ sudah dalam bentuk modul yang telah mempunyai rangkaian pengkondisi sinyal, yang dapat melalui potensiometer sehingga mempunyai pembacaan penguatan sinyal optimal. Arduino Atmega 2560 [15] dipilih untuk keleluasan pengunaan masukan analognya yang berjumlah 16 .

\section{Perancangan Program Akuisisi Data}

Program akuisisi data diperlukan dalam sistem hidung elektronik untuk pengukuran tegangan keluaran dari setiap sensor. Alur proses akuisisi data diperlihatkan pada Gambar 3. Perangkat lunak yang digunakan adalah arduino IDE, Parallax 
Data Acquisition (PLX-DAQ) dan Python. Arduino IDE digunakan untuk mengambil kode yang dapat dibaca manusia dan menerjemahkannya menjadi kode yang dapat dibaca mesin sehingga dapat dieksekusi oleh mikrokontroler untuk menjalankan kendali rangkaian dan aliran gas dari sampel ke larik sensor [12, 14]. PLX-DAQ adalah perangkat lunak yang menghubungkan microsoft excel dengan mikrokontroler untuk memperoleh data. Perangkat lunak akuisisi data paralaks memiliki fitur untuk menganalisis data yang dikumpulkan dari sensor dengan menggunakan spreadsheet [16].

Data yang diperoleh menggunakan aplikasi PLX-DAQ dalam bentuk bit dikonversi ke nilai tegangan menggunakan Persamaan 1. Tegangan referensi adalah nilai tegangan Arduino sebesar 5 volt.

$$
v=\text { Nilai bit } \frac{\text { Tegangan referensi }}{1023}
$$

Data dalam bentuk tegangan diolah menggunakan bahasa Python untuk menentukan luasan daerah dibawah kurva tegangan $\mathrm{L}$ dengan metode integrasi numerik aturan trapezoid mengunakan Persamaan 2. Flowchart program pengolahan data untuk menghitung luasan daerah dibawah kurva (luas trapezoid) ditunjukkan pada Gambar 4. Data tegangan dibaca di platform Python sebagai nilai y, dimana $y=f(x)$ dan $x$ sebagai jumlah data.

$L=\frac{h}{2}\left[f\left(x_{0}\right)+2 \sum_{i=o}^{n-1} f\left(x_{i}\right)+f\left(x_{n}\right)\right.$

Pada Gambar 4, luasan daerah L ditentukan menggunakan library Python yaitu scipy.integrate. Setelah itu, program dijalankan pada Command Prompt Windows, selanjutnya nilai luasan daerah trapezoid diperoleh dalam bentuk file excel [17].

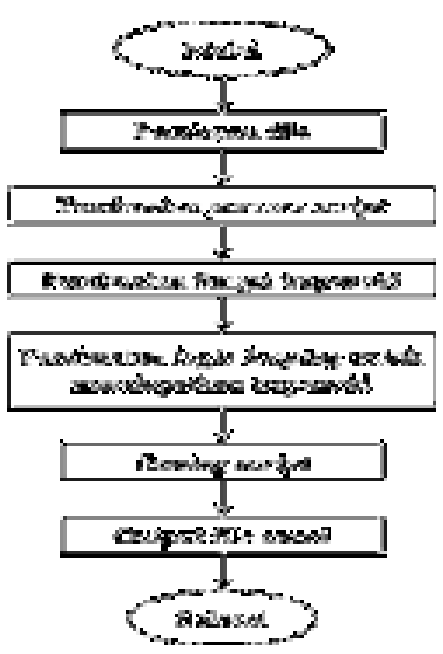

Gambar 3. Alur proses akuisi data

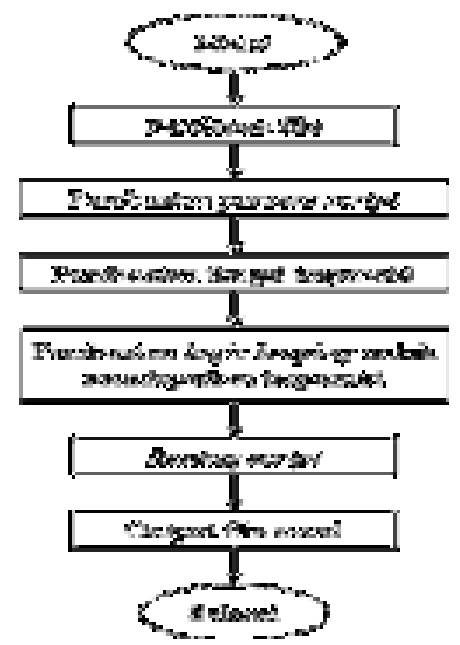

Gambar 4. Flowchart menghitung luasan daerah dibawah kurva tegangan versus waktu melalui pendekatan luas trapezoid

\section{Persiapan Sampel}

Sampel madu yang digunakan pada penelitian ini adalah dua jenis madu dan 1 non madu. Ketiga sampel dinamai masingmasing sampel A yaitu madu bermerek Nasional yang memenuhi SNI 01-35452013, sample B yaitu madu hutan lokal yang langsung diambil dari peternak madu, dan sampel C sari kurma. Sebelum sampel dideteksi menggunakan sistem hidung elektronik, kadar gula dan $\mathrm{pH}$ ketiga jenis madu diukur terlebih dahulu. Kadar gula 
Minarni Shiddiq, dkk.: Rancang Bangun Sistem Hidung Elektronik Berdasarkan Sensor Gas MQ untuk Menentukan Kualitas Madu

diukur menggunakan Refraktometer-Brix dan $\mathrm{pH}$ diukur menggunakan $\mathrm{pH}$ meter digital [18]. Nilai pH dan kadar gula sampel A, B, dan $\mathrm{C}$ dijelaskan pada Tabel 2. Pada Tabel 2, sampel $\mathrm{C}$ mempunyai nilai $\mathrm{pH}$ yang tinggi.

\section{Pengambilan Data Tegangan Keluaran}

Sampel diletakkan dalam cawan petri sebanyak $40 \mathrm{~mL}$ agar aroma dapat menyebar karena sampel berupa cairan membutuhkan permukaan yang luas. Cawan petri dimasukkan kedalam chamber berbentuk tabung. Aroma dihisap menggunakan pompa vakum melewati selang gas pada waktu ke 180 detik yang telah diatur pada kodingan arduino dengan LM 317 sebagai gerbang logikanya. Aroma masuk ke ruang sensor gas dan dideteksi selama 60 detik. Setelah itu, aroma sampel dikeluarkan menggunakan pompa vakum. Data ditampilkan pada komputer secara real time dengan bantuan PLX-DAQ.

Waktu yang dibutuhkan dalam sekali pengukuran yaitu 300 detik. Waktu sebelum mendeteksi aroma sampel dari 1180 detik, Keadaan ini disebut steady state, dimana grafik terlihat konstan. Hal ini menunjukkan bahwa tidak ada aroma lain yang terdapat pada kotak sensor gas. Waktu 180 detik juga merupakan waktu pemanasan sensor gas, karena sensor gas dapat mendeteksi aroma dengan baik saat sensor sudah panas.

Waktu 241- 300 detik adalah waktu pengeluaran aroma yang ada dalam kotak sensor gas, grafik mulai turun.

Tabel 2. Karakteristik kimia Sampel Madu

\begin{tabular}{ccccc}
\hline No & Kode & Merek & \multicolumn{1}{l}{$\begin{array}{l}\text { Kadar } \\
\text { Gula }\end{array}$} & $\mathrm{pH}$ \\
\hline 1 & A & Nasional & $76 \%$ & 3,7 \\
2 & B & Madu & $62 \%$ & 3,4 \\
& & Hutan & & \\
3 & C & Sari kurma & $72 \%$ & 4,4 \\
\hline
\end{tabular}

Aroma yang terdapat dalam kotak sensor gas dibuang melalui pompa vakum ke arah luar. Namun data yang digunakan hanya saat mendeteksi aroma sampel, yaitu data di detik 175-245, saat waktu inilah terlihat kenaikan dan penurunan grafik yang menunjukkan respon sensor saat mendeteksi aroma, data ini disebut data collecting.

\section{HASIL DAN PEMBAHASAN}

Prototipe sistem hidung elektronik yang telah dibangun diperlihatkan pada pada Gambar 5. Sistem ini terdiri dari dua bagian yaitu ruang sampel dan ruang sensor beserta Arduino, selanjutnya sistem aliran fluida dari aroma madu dari ruang sampel ke ruang sensor mengunakan pompa vakum. Sistem dilengkapi perangkat lunak yang digunakan untuk pembacaan tegangan setiap sensor (Arduino IDE), konversi data bit dari PLX-DAQ) menjadi tegangan dan disusun dalam file excel, serta perhitungan luas daerah trapezoid setiap fungsi tegangan (Python).

Respon setiap sensor gas MQ berbeda saat mendeteksi sampel. Hal ini menunjukan sensitivitas sensor gas yang digunakan. Keenam sensor pada sistem hidung elektronik mampu merespon dengan aroma madu dengan baik seperti ditunjukkan oleh Gambar 6.

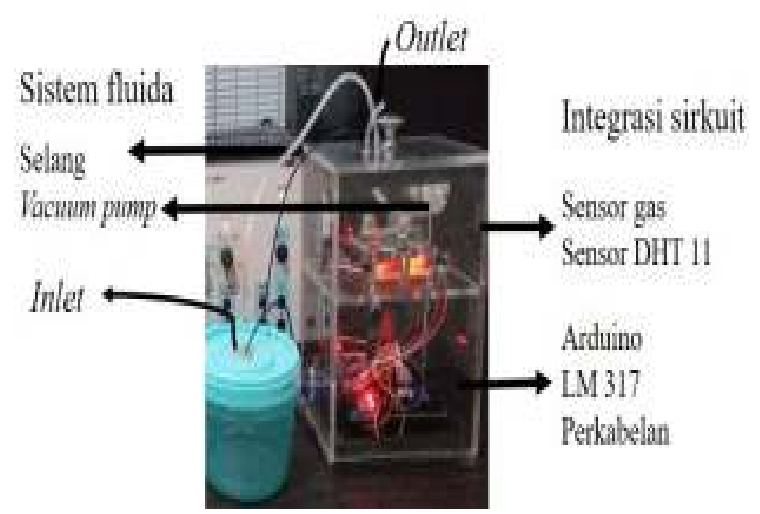

Gambar 5. Prototipe sistem hidung elektronik 


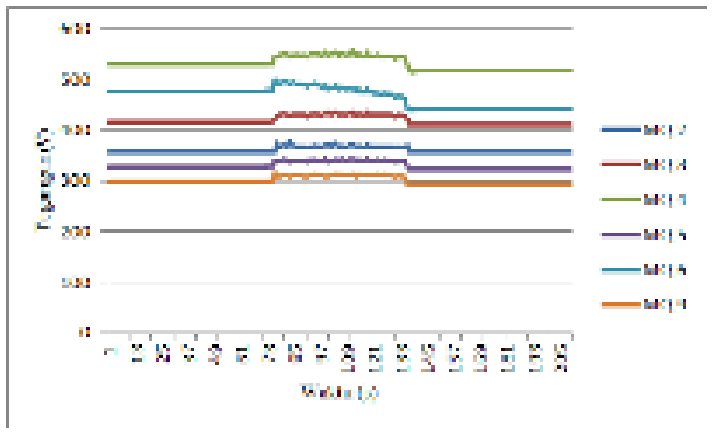

Gambar 6. Respon sensor gas pada serial plotter Ardunio untuk Madu SNI (Madu A)

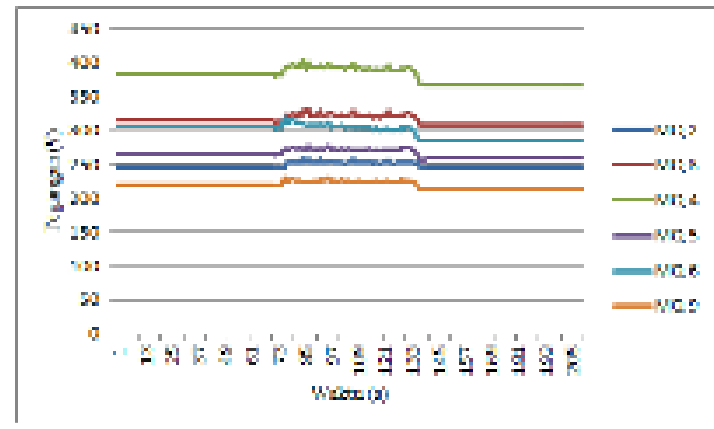

Gambar 7. Respon sensor gas pada serial plotter Ardunio untuk Madu Hutan (Madu B)

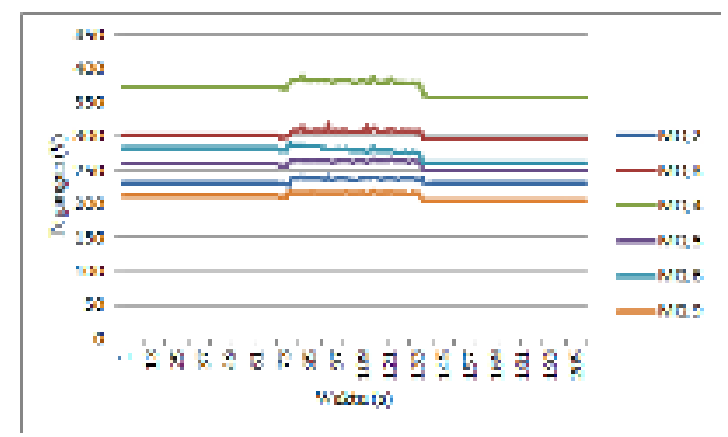

Gambar 8. Respon sensor gas pada serial plotter Ardunio untuk Sari Kurma

Gambar 6, 7, dan 8 memperlihatkan respon ke enam sensor terhadap proses pengambilan data masing-masing madu SNI, madu hutan, dan sari kurma (non madu) setelah data bit diubah ke data tegangan. Sensor MQ 4 mempunyai tegangan keluaran yang lebih tinggi untuk ketiga jenis sampel, diikuti oleh sensor MQ 3 untuk Madu A dan sari kurma, dan MQ 6 untuk madu A. Sensor MQ 2 dan MQ 5 mempunyai tegangan keluaran yang lebih kecil, sementara sensor MQ 9 memperlihatkan respon yang paling kecil.

Respon masing-masing sensor dianalisa dalam bentuk luasan daerah dibawah kurva tegangan terhadap waktu. Luasan daerah dibawah kurva dihitung menggunakan metode integrasi numerik aturan trapezoid sehingga disebut luasan daerah atau luas trapezoid. Metode integrasi numerik aturan trapezoid digunakan pada penelitian ini karena memiliki error yang kecil.

Tabel 3 memperlihatkan nilai luas trapezoid setiap sensor pada setiap jenis madu dan non madu. Nilai rata-rata luas trapezoid paling tinggi dimiliki oleh jenis madu bermerk nasional dimana nilai $\mathrm{pH}$ dan kadar gulanya sudah memenuhi SNI 01-3545-2013 (Tabel 1) diikuti oleh madu hutan yaitu sampel $B$, dan yang terendah diperoleh untuk sari kurma (sampel C) walaupun $\mathrm{pH}$ dan kadar gulanya lebih tinggi dari madu B. Sensor MQ 4 memberi respon paling tinggi diikuti sensor MQ 6 dan MQ 3. Sensor MQ 6 memperlihatkan perbedaan nilai antara ketiga sensor lebih tinggi atau dapat membedakan ketiga jenis sampel lebih baik. 
Minarni Shiddiq, dkk.: Rancang Bangun Sistem Hidung Elektronik Berdasarkan Sensor Gas MQ untuk Menentukan Kualitas Madu

Tabel 3. Nilai luas trapezoid setiap sensor terhadap sampel

\begin{tabular}{lcrr}
\hline $\begin{array}{l}\text { Jenis } \\
\text { sensor gas }\end{array}$ & $\mathrm{A}$ & \multicolumn{1}{c}{$\mathrm{B}$} & \multicolumn{1}{c}{$\mathrm{C}$} \\
\hline MQ 2 & 124,70 & 87,62 & 81,28 \\
MQ 3 & $\mathbf{1 4 5 , 2 4}$ & $\mathbf{1 1 0 , 6 4}$ & $\mathbf{1 0 5 , 0 9}$ \\
MQ 4 & $\mathbf{1 8 5 , 2 0}$ & $\mathbf{1 3 3 , 7 7}$ & $\mathbf{1 2 8 , 9 2}$ \\
MQ 5 & 114,28 & 92,80 & 89,39 \\
MQ 6 & $\mathbf{1 6 2 , 1 4}$ & $\mathbf{1 0 3 , 2 7}$ & $\mathbf{9 6 , 2 5}$ \\
MQ 9 & 104,82 & 77,24 & 73,41 \\
Rata-rata & 139,40 & 100,89 & 95,72 \\
\hline
\end{tabular}

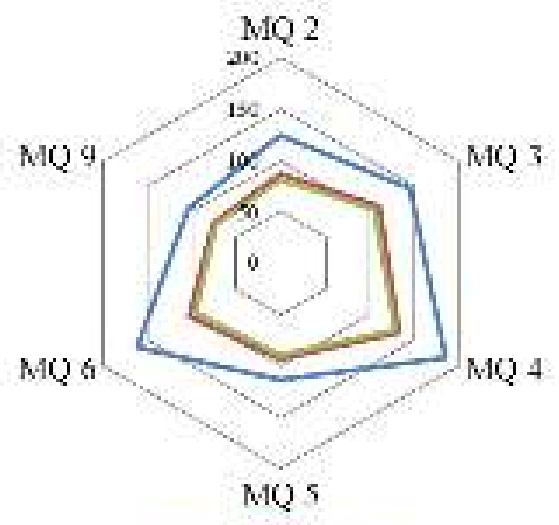

Gambar 9. Grafik hubungan luasan daerah trapezoid setiap sensor gas

Dari Tabel 3, pola radar dari ke enam sensor gas MQ terhadap tiga sampel madu berdasarkan luas trapezoid dibuat seperti diperlihatkan pada Gambar 9. Setiap pola yang terbentuk dari masing-masing sampel merupakan susunan kenaikan tegangan keluaran tiap sensor gas yang terpapar aroma atau gas dari sampel madu yang diwakili dengan luasan daerah trapezoid. Gambar 9 lebih menjelaskan bahwa sensor gas yang mempunyai sensitivitas lebih tinggi terhadap ketiga jenis madu adalah MQ 4, MQ 6 dan MQ 3.

Sensor gas MQ 4, MQ 6, dan MQ 3 mempunyai respon sangat tinggi dibanding sensor lainnya. Jenis gas utama yang dapat di deteksi oleh setiap sensor diberikan oleh Tabel 1. Namun setiap sensor dapat mendeteksi jenis gas lainnya namun dengan sensitivitas lebih kecil. Menurut referensi
[10], senyawa volatil yang dikandung oleh berbagai jenis madu mencapai 59 jenis senyawa, 13 diantaranya termasuk dalam kelompok alkohol, 11 senyawa aldeheida, 10 senyawa asam, 9 senyawa ester, 4 senyawa keton, 3 senyawa heterosiklik, 3 senyawa fenol, dan 2 senyawa alkana. Sensor MQ 4, MQ 6, dan MQ 3 mempunyai sensitivitas pada senyawa alkana yaitu propana dan butana yaitu merupakan komposisi utama dari gas Liquefied Petroleum Gas (LPG). Sensitivitas terhadap alkohol lebih kecil. Menurut referensi [14], sensor gas seri MQ yang dominan untuk berbagai madu seperti ditunjukkan Tabel 1 adalah sensor MQ 4, MQ 6, dan MQ 5, karena ketiganya sangat sensitif terhadap gas LPG. Namun dalam penelitian ini MQ 3 juga menghasilkan nilai luas trapezoid yang tinggi. Studi lebih lanjut mengunakan Gas Cromathography Mass Spectrometry (GC-MS) untuk komposisi senyawa volatil ketiga jenis sampel diperlukan.

Sifat fisika dan kimia madu sangat penting sebagai parameter untuk menentukan kualitas madu. Kadar air (moisture content), kadar gula total, nilai $\mathrm{pH}$, konduktivitas, dan viskositas merupakan parameter kualitas madu yang sering diukur untuk menentukan kualitas madu $[6,7]$. Pengembangan alat ukur yang non destruktif, cepat, real time gencar dilakukan, salah satunya mengunakan hidung elektronik. Hubungan antara besaran fisika dan kimia dengan tegangan yang dihasilkan oleh setiap sensor hidung elektronik perlu dianalisa untuk memperoleh sensor-sensor gas yang sesuai

Menurut referensi [14], hubungan yang kuat antara nilai $\mathrm{pH}$ dan luas daerah trapezoid dengan koefisien tertinggi ditunjukkan oleh sensor MQ 4, MQ 5, dan MQ 6 berkisal dari 0,765 - 0,865, dan cukup kuat untuk nilai kandungan air (moisture content) terhadap nilai tegangan 
yaitu $0,635-0,7$ untuk ketiga sensor. Hasil ini dapat menjelaskan mengapa nilai luas trapezoid non madu sari kurma lebih rendah karena nilai pHnya lebih tinggi. Kadar gula berbanding terbalik dengan kadar air. Kedua parameter ini mempunyai hubungan yang erat dengan hasil tegangan sensor yang dihasilkan.

\section{KESIMPULAN}

Berdasarkan penelitian yang telah dilakukan, hanya tiga dari enam sensor gas yang digunakan yang memiliki respon tegangan keluaran yang paling tinggi yaitu MQ3, MQ4, dan MQ6. Ini berhubungan dengan sensitivitas ketiga sensor terhadap kandungan senyawa volatil dari jenis madu dan non madu. Madu SNI memiliki Luas Trapezoid tertinggi diikuti oleh madu hutan lokal dan sari kurma (non madu). Dari hasil luasan trapezoid rata-rata, ke enam sensor dapat membedakan dua jenis madu dan non madu dengan baik. Namun sensor MQ 6 membedakan paling baik. Besarnya nilai kadar gula dan nilai $\mathrm{pH}$ madu memperlihatkan hubungan yang kuat dengan besarnya nilai tegangan yang dikeluarkan oleh setiap sensor. Komposisi senyawa volatil yang terkandung pada ketiga jenis sampel madu perlu diteliti lebih jauh. Sistem hidung elektronik ini potensial untuk digunakan sebagai pembeda jenis madu.

\section{DAFTAR PUSTAKA}

[1] S. Magdalena and W. Wardencki, "Food Analysis Using Artificial Senses," 2014.

[2] M. T. Kalit, K. Marković, S. Kalit, N. Vahčić, and J. Havranek, "Application of electronic nose and electronic tongue in the dairy industry," Mljekarstvo, vol. 64, no. 4, pp. 228-244, 2014, doi: 10.15567/mljekarstvo.2014.0402.

[3] S. Kiani, S. Minaei, and M.
Ghasemi-Varnamkhasti, "Fusion of artificial senses as a robust approach to food quality assessment," J. Food Eng., vol. 171, no. October, pp. 230239, 2016, doi: 10.1016/j.jfoodeng.2015.10.007.

[4] D. Karakaya, O. Ulucan, and M. Turkan, "Electronic Nose and Its Applications: A Survey," Int. J. Autom. Comput., vol. 17, no. 2, pp. 179-209, 2020, doi: 10.1007/s11633-019-1212-9.

[5] S. A. Meo, S. A. Al-Asiri, A. L. Mahesar, and M. J. Ansari, "Role of honey in modern medicine," Saudi $J$. Biol. Sci., vol. 24, no. 5, pp. 975978, 2017, doi: 10.1016/j.sjbs.2016.12.010.

[6] Evahelda, F. Pratama, N. Malahayati, and B. Santoso, "The Changes of Moisture Content, $\mathrm{pH}$, and Total Sugar Content of Honey Originated from the Flowers of Bangka Rubber Tree during Storage," Int. J. Sci. Eng. Res., vol. 5, no. 5, pp. 33-36, 2017, [Online]. Available: https://www.ijser.in/IJSER151372.

[7] N. Putu et al., "Kualitas Madu Lokal dari Beberapa Wilayah di Kabupaten Temanggung The Local Honey Quality of Some Areas in Temanggung," vol. 2, pp. 58-66, 2017.

[8] Agus A Munawar, Yusmanizar, Hafidh, and Zulfahrizal, "Kajian Teknologi Near Infrared Spectroscopy Sebagai Metode Baru untuk Prediksi Kualitas Madu," Pros. Semin. Nas. Pascasarj. Unsyiah, pp. 27-31, 2017.

[9] C. E. Manyi-Loh, R. N. Ndip, and A. M. Clarke, "Volatile compounds in honey: A review on their involvement in aroma, botanical origin determination and potential biomedical activities," Int. J. Mol. Sci., vol. 12, no. 12, pp. 9514-9532, 
Minarni Shiddiq, dkk.: Rancang Bangun Sistem Hidung Elektronik Berdasarkan Sensor Gas MQ untuk Menentukan Kualitas Madu

2011, doi: 10.3390/ijms12129514.

[10] H. Tian, Y. Shen, H. Yu, and C. Chen, "Aroma features of honey measured by sensory evaluation, gas chromatography-mass spectrometry, and electronic nose," Int. J. Food Prop., vol. 21, no. 1, pp. 1755-1768, 2018 , doi: 10.1080/10942912.2016.1213744.

[11] D. Laksono and M. Chairiawan, "Karakterisasi Pola Aroma Salak Pondoh dengan E-Nose Berbasis Sensor Metal Oksida," IJEIS (Indonesian J. Electron. Instrum. Syst., vol. 3, no. 1, pp. 71-82, 2013, doi: $10.22146 /$ ijeis.3840.

[12] K. Triyana, M. Taukhid Subekti, P. Aji, S. Nur Hidayat, and A. Rohman, "Development of Electronic Nose with Low-Cost Dynamic Headspace for Classifying Vegetable Oils and Animal Fats," Appl. Mech. Mater., vol. 771, pp. 50-54, 2015, doi: 10.4028/www.scientific.net/amm.77 1.50 .

[13] S. Kiani, S. Minaei, and $M$. Ghasemi-Varnamkhasti, "A portable electronic nose as an expert system for aroma-based classification of saffron," Chemom. Intell. Lab. Syst., vol. 156, no. May, pp. 148-156, 2016, doi: 10.1016/j.chemolab.2016.05.013.

[14] S. Faal, M. Loghavi, and S. Kamgar, "Physicochemical properties of Iranian ziziphus honey and emerging approach for predicting them using electronic nose," Meas. J. Int. Meas. Confed., vol. 148, p. 106936, 2019, doi:

10.1016/j.measurement.2019.106936

[15] M. Mckinnon, Arduino, 1st ed. CreateSpace Independent Publishing Platform, 2016.

[16] M. V. Sreenivas Rao and M. Shivakumar, "PLX-DAQ-based wireless battery monitoring system for obstacle avoidance robot," Lect. Notes Electr. Eng., vol. 581, no. January, pp. 133-140, 2020, doi: 10.1007/978-981-13-9419-5_12.

[17] C. R. Severance, Python for Everybody, 1st ed. ann arbor, 2013.

[18] F. Lismayeni, S. Fitriadhani, H. Adzani, N. Yasmin Zakyyah, and Minarni, "Karakterisasi Sifat Fisika Dan Kimia Madu Asli Riau Menggunakan Metode Optik," no. September, pp. 1-5, 2018. 